\title{
Economic Development: The Dismal Science
}

\author{
Anthony Daniels
}

Development economists - at least, those whose books found their way into the bookstores for the general public-used for many years to ask where poverty came from, as if wealth were the natural state of Mankind. They were like epistemologists who sought the origins of human ignorance.

The answer was clear, at least for most of them: poverty was the result of exploitation, as likewise was wealth. In fact, they were two sides of the same coin, the coin being the world economic system.

There are two ways of speaking of wealth and poverty, the absolute and the relative. They are often confused and abused, usually for ideological purposes. In the relative sense, wealth and poverty are of course dialectically related: and the poor in one society may be rich by the standards of another. In a society of billionaires, a mere millionaire would be poor, whatever his standard of living in the absolute sense. The ratio of Jeff Bezos's wealth to mine is much greater than that of mine to the poorest person in my society: but it would be absurd to call me poor or impoverished. The poverty line in many societies, however, is now defined as an income below 60 per cent the median income, irrespective of what that median is; and thus a person living in abundance could be said also to be living in poverty, with all the connotations of near-destitution transferred to the denotation of his actual situation, no matter how prosperous in the absolute sense.

The development economists meant by their theory more than that poor countries were poor only in relative terms: they meant that they were actively impoverished by the rich countries, their wealth sucked out of them as a leech or a vampire bat sucks blood. Rich countries were rich because they had exploited poor countries, which in turn were poor because rich countries had exploited them.

Anthony Daniels is a contributing editor to City Journal and Dietrich Weismann Fellow at the Manhattan Institute; anthonymalcolmdaniels@gmail.com 
This gave rise to the idea that foreign aid from rich countries to poor was not generous or charitable but compliance with the moral duty of restitution of what had rightfully belonged to the poor countries in the first place. It was the return by thieves of stolen goods to their proper owners.

There was another explanation of the poverty of nations current at the time: that poor countries were poor because they lacked the capital by means of which they could develop. This, in effect, amounted to saying that poor countries were poor because they were poor, for lack of capital is not a cause of poverty, it is poverty itself.

On this view, there were two possible sources of capital for poor countries: forced saving or foreign aid-not mutually exclusive, of course. Forced saving was achieved by obliging peasants to sell their surplus produce to the government or a government agency at below market value, the difference (in theory) accruing to government that would then use it as capital to develop the economy. It took a special kind of naivety, possible only for intellectuals, to believe that this would actually happen.

Private foreign investment, unlike that made by the state, was decried because it was in search of profit for itself, not for the good of the country. For example, if private capital opened a mine, it returned to the country less than the full value of what was mined. This supposed loss was more important than the fact that, if the foreign investment were not made, nothing at all would have been mined or, if foreign aid had been available, mined by a state company of startling inefficiency and corruption that returned far less to the national economy than even the most rapacious private enterprise would have done. Professed moral intention, however, was more important (as it so often is) than any results actually accomplished.

Foreign aid was supposed to work directly for the recipient country's general benefit, without private or personal interest intervening to reduce its effect. It was utopian as to human nature. Needless to say, the reality was very different. Aid corrupted both the donors and the recipients. I was able to observe the effect of foreign aid close up in Africa, in Tanzania to be precise, the Sub-Saharan country that received more aid per head than any other in Africa and yet remained firmly and stubbornly among the poorest. Money was poured through it like water through sand.

I was doctor to a large construction project funded by British aid. A road was to be built that would allegedly open the commerce of a hitherto isolated area 
of the country, difficult of access. The strange thing was that the government of the time, being African socialist, was extremely hostile to all commerce except such as it controlled itself, because it believed that private commerce aimed at individual rather than collective benefit, which was immoral and not in accordance with African tradition. (I need hardly add that this was not at all incompatible with the personal enrichment of government officials, members of the only permitted political party, the Party of the Revolution, being often recognizable by their girth alone.)

The first fruits of the project were the excellent housing for the expatriates who worked on it. Their standard of living was far an improvement on anything they could have experienced at home. Their tax-free salaries were excellent and their expenses minimal. A stint working in foreign aid was the means by which many of them set themselves up at home and saw the world into the bargain; for others, it had become a pleasant and lucrative way of life, as they went from aid project to aid project. There was little incentive to carry out the work efficiently or expeditiously, rather the reverse. As for me, my first house was bought with the proceeds of foreign aid. Only a very tiny proportion of the people working in foreign aid retained any idea that they were doing anything useful, let alone essential, for the country in which they worked.

Foreign aid corrupted the recipient country even further. For example, it made possible deleterious policies that would otherwise not have been possible. Scandinavian aid was essential to Tanzania as it implemented its economically disastrous villagization policy, which herded millions of peasants into collectivized villages against their will and caused agricultural production (the occupation of the great majority of the country's population) to decline drastically, to the point where only further foreign aid prevented outright starvation. The worse things became, thanks in part to foreign aid, the more essential did it become. It took a long time for the Scandinavians to acknowledge this, but eventually they did.

No doubt small-scale aid initiatives sometimes work, and it would be difficult to expend billions without any benefit whatever accruing to recipient populations, even if mostly due to corrupt elites. But the whole theoretical basis on which foreign aid was predicated was false and rather condescending, implying as it did that there were whole countries and populations that were incapable of advancement by their own efforts and which required the humanitarian assistance of their civilizational superiors. It is hardly 
surprising that there has been no country that has developed principally as a result of foreign aid, which has proved neither necessary nor sufficient for such development. 